\title{
Effects of Extraction Solvents on Phytochemical Screening, Cytotoxicity and Anti-Obesity Activities of Selected Sri Lankan Medicinal Plants
}

\author{
Silva Waruni Randika ${ }^{1,2}$, Nugara Ruwani Nilushi ${ }^{1, *}$, Manage Pathmalal ${ }^{2,3}$, Undugoda Lanka ${ }^{1}$, \\ Udayanga Dhanushka', Liyanage Renuka Nilmini ${ }^{4}$, Galhena Prasanna ${ }^{5}$
}

\section{Silva Waruni Randika ${ }^{1,2}$, Nugara Ruwani Nilushi ${ }^{1}, *$, Manage Pathmalal',3, Undugoda Lanka', Udayanga Dhanushka', Liyanage Renuka Nilmini ${ }^{4}$, Galhena Prasanna ${ }^{5}$}

'Department of Biosystems Technology, Faculty of Technology, University of Sri Jayewardenepura, Gangodawila, Nugegoda, SRI LANKA.

${ }^{2}$ Faculty of Graduate Studies, University of Sri Jayewardenepura, Gangodawila, Nugegoda, SRI LANKA.

${ }^{3}$ Centre for Water Quality and Algae Research, Department of Zoology, Faculty of Applied Sciences, University of Sri Jayewardenepura, Gangodawila, Nugegoda, SRI LANKA.

${ }^{4}$ Department of Materials and Mechanical Technology, Faculty of Technology, University of Sri Jayewardenepura, Gangodawila, Nugegoda, SRI LANKA. ${ }^{5}$ Department of Biochemistry and Clinical Chemistry, Faculty of Medicine, University of Kelaniya, SRI LANKA.

Correspondence

\section{Dr. Ruwani N Nugara}

Department of Biosystems Technology, Faculty of Technology, University of Sri Jayewardenepura, Gangodawila, Nugegoda, SRI LANKA.

Phone no: +94112758000

Email id: nilushinug@sjp.ac.lk

\section{History}

- Submission Date: 30-06-2021

- Review completed: 14-07-2021

- Accepted Date: 28-08-2021

\section{DOI : 10.5530/pres.13.4.18}

Article Available online

http://www.phcogres.com

Copyright

(C) 2021 Phcog.Net. This is an openaccess article distributed under the terms of the Creative Commons Attribution 4.0 International license.

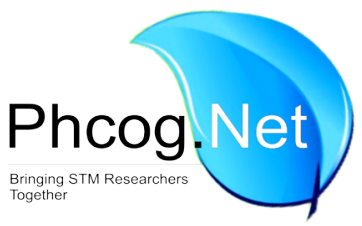

\begin{abstract}
Background: Phytoconstituents are known to have an arena of health benefits. The choice of extraction solvents for a desired pharmacological activity is poorly characterized. Objectives: The present study compared the use of different solvents to extract phytoconstituents, evaluate cytotoxicity and anti-obesity activities. Materials and Methods: Leaves, bark, flowers or tubers of fourteen commonly utilized plants in the Sri Lankan Ayurvedic system were used to prepare extracts of distilled water (DW), ethanol or $n$-hexane. Phytochemical screening, total phenolic and flavonoid contents (TPC and TFC), cytotoxicity and triglyceride assays were performed. Results: DW served as the best solvent to extract the highest yield of phytochemicals followed by ethanol marking hexane as the least efficient solvent. The water extract (WE) of Averrhoa bilimbi leaves and ethanol extract (EE) of Cassia auriculata showed the highest TPC. The TFC was lowest in the hexane extract (HE) of all plants. The WE of plants showed $\geq 75 \%$ cell viability below $500 \mu \mathrm{g} / \mathrm{mL}$ with no potential anti-adipogenic activity. The EE of Justicia adhathoda showed maximum lipid inhibition (88.31\%), followed by Aerva lanata (74.65\%), and Cyperus rotundus (74.04\%) at $100 \mu \mathrm{g} / \mathrm{mL}$. The EE of Ipomoea aquatica (45.11\%), Murrya koenigii (41.04\%), and Hemidesmus indicus (32.97\%) showed the highest viable anti-adiposity activity at $50 \mu \mathrm{g} / \mathrm{mL}$. Conclusion: The WE of most plants provided a greater yield of phytoconstituents enabling their safe usage in higher doses during Ayurvedic medication. Ethanol served as a better solvent to extract constituents responsible for anti-adipogenesis and no possible correlation was found between the phenolic content and anti-adiposity.
\end{abstract}

Key words: 3T3-L1, Anti-adipogenesis, Ayurveda, Cytotoxicity, Phytochemicals, Medicinal plants.

\section{Key Message}

- $\quad$ Fifteen commonly used medicinal plant parts in Ayurvedic medication in Sri Lanka were screened in the present study.

- $\quad$ Distilled water, ethanol and $n$-hexane were used to prepare extracts and evaluated them to obtain a higher yield of phytoconstituents, tested the total phenolic and flavonoid contents.

- $\quad$ The potential extracts were used to investigate the cytotoxicity and anti-adiposity.

- The presence of flavonoids, tannins, terpenoids, alkaloids, steroids, anthocyanins and coumarins were confirmed in both water and ethanol extracts. However, saponins and leucoanthocyanins were not found in any of the extracted solvents.

- Many of the water extracts of plants showed no cytotoxicity even at $500 \mu \mathrm{g} / \mathrm{mL}$, whereas the crude ethanol extracts of plants showed a diversification in their concertation levels to maintain cell viability depending on the plant, however, was limited to levels below $100 \mu \mathrm{g} / \mathrm{mL}$.

- No possible correlation was found between the available phenolic content of extracts and anti-adipogenic activity.

- This study provides information to be used as a diagnostic tool for the correct identification of aqueous or ethanolic extracts and the development of a standardized pharmaceutica product that may be used by healers in Ayurvedic medication system.

\section{INTRODUCTION}

Plants not only act as dietary supplements they also play a beneficial role in treating many health problems in both humans and animals. Medicinal plants are utilized around the world under different name

categories such as Ayurveda in Sri Lanka, Unani and Siddhi in India, Kampo in Japan, and the Janui in Indonesia. ${ }^{[1]}$ Plants are rich sources of useful secondary metabolites that can be utilized for treating

Cite this article: Silva WR, Nugara RN, Manage P, Undugoda L, Udayanga D, Liyanage RN, Galhena P. Effects of Extraction Solvents on Phytochemical Screening, Cytotoxicity and Anti-Obesity Activities of Selected Sri Lankan Medicinal Plants. Pharmacog Res. 2021;13(4):246-56. 
a vast range of diseases and disorders. These phytoconstituents are usually acquired from different plant parts such as leaf, flower, bark, twig, stem, and tuber contributing directly as therapeutic agents. ${ }^{[2]}$ With the isolation of active compounds or through successive fractionations, these products occupy a greater proportion in the nutraceutical industry due to their wide spectrum of biochemical activities. ${ }^{[3-5]}$

Sri Lanka has been gifted with vast fauna and flora collection by nature, thus, hundreds of plants have been identified as therapeutic agents over centuries. In time-honored traditional systems of medicine, regular usage of many herbs have been conventionally recommended in managing different diseases. Most of the herbal mixtures used therein consist of water extract of several common plant parts in crude mixtures, locally named as 'kalka', with poor scientific support to prove its traditional claims. Out of 1,430 medicinal plant species, 250 species are regular ingredients in the traditional Ayurvedic system ${ }^{[6]}$ with limited screening studies carried out to elucidate beneficial phytoconstituents. In addition to the climatic conditions in which the plants grow, the concentration of extractable phenolic and other secondary metabolites is influenced by the method of extraction, and selection of extraction solvent is poorly characterized against cytotoxicity in previous studies. ${ }^{[7,8]}$

In the present study, we used leaves of Aerva lanata (L.) Juss. ex Schult. (Polpala), Cassia auriculata L. (Ranawara), Centella asiatica (L.) Urban (Gotukola), Alysicarpus vaginalis (L.) DC. (Aswenna), Justicia adhathoda L. (Adhathoda), Averrhoa bilimbi L. (Bilin), Hemidesmus indicus (L.) R. Br. (Iramusu), Ipomoea aquatica Forssk. (Kankun), Murraya koenigii (L.) Spreng. (Karapincha), and Asparagus falcatus L. (Hathavariya), bark of Salacia reticulata (Kothalahimbutu), stem of Tinospora cordifolia (Willd.) Hook. f. and Thoms. (Rasakinda), flowers of Averrhoa bilimbi L. (Bilin) and Aegle marmelos (Beli), and tubers of Cyperus rotundus L. (Kalanduru). In the Ayurvedic medication system, these plants are used for healing various ailments such as snakebites, urinary tract infections, anorexia, asthma, abdominal colic and pain, diabetes, dysentery, diarrhea, cough, rheumatism, fever, headache, inflammation, skin diseases, sore eyes, and cancer with a paucity of research evidence on anti-obesity properties. Thus, the attempt was to compare the efficiency of different extracting solvents to extract various phytochemicals from the fourteen medicinal plants and assess the effect of each extract on cell viability and anti-obesity.

\section{MATERIALS AND METHODS}

\section{Plant materials}

Fresh leaves, flowers, bark, stem, and tubers were obtained from fourteen selected plant species. A. lanata (leaves), C. auriculata (leaves), C. asiatica (leaves), A. vaginalis (leaves), J. adhathoda (leaves), A. bilimbi (leaves and flowers), H. indicus (leaves), I. aquatica (leaves), M. koenigii (leaves), A. falcatus (leaves), S. reticulata (bark), T. cordifolia (stem), A. marmelos (flowers) and C. rotundus (tubers) were collected from the dry zone in Sri Lanka. All plant parts were identified at the laboratory of National Herbarium, at the Department of National Botanical Garden under the supervision of Dr. R. A. S. W. Ranasinghe (NH/BOT/4/2020-01 and 2020-24). A detailed description of the selected fifteen plant parts from fourteen medicinal plants is illustrated in Table 1.

\section{Chemicals and reagents}

Quercetin, gallic acid, aluminum chloride, sodium nitrite, isoamyl alcohol, Dulbecco's modified Eagle medium (DMEM), fetal bovine serum (FBS), phosphate-buffered saline (PBS), Oil Red O (ORO), isopropyl alcohol, and formalin were purchased from Sigma Chemical Co. (St. Louis, USA). Ethanol, $n$-hexane, sodium hydroxide, chloroform, and dimethyl sulfoxide (DMSO), ammonia was purchased from DAEJUNG
Table 1: List of selected fourteen plants used for the experiments.

\begin{tabular}{|c|c|c|c|}
\hline Scientific name & Plant family & Common name & Portion \\
\hline $\begin{array}{c}\text { Aerva lanata (L.) Juss. ex } \\
\text { Schult. }\end{array}$ & Amaranthaceae & Polpala & Leaves \\
\hline Averrhoa bilimbi (L.) & Oxalidaceae & Bilin & $\begin{array}{c}\text { Flowers/ } \\
\text { Leaves }\end{array}$ \\
\hline $\begin{array}{l}\text { Murraya koenigii (L.) } \\
\text { Spreng. }\end{array}$ & Rutaceae & Karapincha & Leaves \\
\hline $\begin{array}{c}\text { Alysicarpus vaginalis (L.) } \\
\text { DC. }\end{array}$ & Fabaceae & Aswenna & Leaves \\
\hline $\begin{array}{c}\text { Hemidesmus indicus (L.) } \\
\text { R. Br. }\end{array}$ & Apocynaceae & Iramusu & Leaves \\
\hline Ipomoea aquatica Forssk. & Convolvulaceae & Kankun & Leaves \\
\hline $\begin{array}{c}\text { Tinospora cordifolia } \\
\text { (Willd.) Hook. f. and } \\
\text { Thoms. }\end{array}$ & Menispermaceae & Rasakinda & Stem \\
\hline Cassia auriculata (L.) & Fabaceae & Ranawara & Leaves \\
\hline Asparagus falcatus (L.) & Asparagaceae & Hathavariya & Leaves \\
\hline $\begin{array}{c}\text { Centella asiatica (L.) } \\
\text { Urban }\end{array}$ & Apiaceae & Gotukola & Leaves \\
\hline Justicia adhathoda (L.) & Acanthaceae & Adhathoda & Leaves \\
\hline Cyperus rotundus (L.) & Cyperaceae & Kalanduru & Tubers \\
\hline Aegle marmelos & Rutaceae & Beli & Flowers \\
\hline Salacia reticulata & Hippocrateaceae & Kothalahimbutu & Bark \\
\hline
\end{tabular}

(Gyeonggi-do, Korea). Folin - Ciocalteu was purchased from VWR chemicals (France) and all other chemicals were in analytical grade.

\section{Preparation of the plant crude extracts}

The plant parts were stored at $-80^{\circ} \mathrm{C}$ for one week, crushed, freezedried and powdered. Plant extracts were prepared using pure ethanol, $n$-hexane, and distilled water (DW) using the following procedure: one gram of powdered samples were separately dissolved in $25 \mathrm{~mL}$ ethanol (99.9\%), DW, or $n$-hexane. Samples were vigorously shaken by hand and placed in a shaker (GEMMY Orbit Shaker, Taiwan) at $250 \mathrm{rpm}$, overnight at room temperature. The mixtures were then centrifuged at 3,000 $\mathrm{rpm}$ for $10 \mathrm{~min}$. The supernatants were collected to a new centrifuge tube and filtered through Polyethersulfone (PES, $0.45 \mu \mathrm{m}$ ) or Polytetrafluoroethylene (PTFE, $0.45 \mu \mathrm{m}$ ) filter membranes and was freshly used for the phytoconstituent analysis. For the in vitro studies, the resulting filtrates were measured and rotary evaporated. Dried pellets were re-dissolved in DMSO to a known concentration as the master stock and maintained the DMSO level in medium below $0.4 \%$ and kept at $-20^{\circ} \mathrm{C}$ until further use.

\section{Phytochemical Screening}

Preliminary qualitative phytochemical screening was conducted using standard methods as described previously. ${ }^{[9-11]}$

\section{Test for alkaloids (Wagner's test)}

Wagner's reagent: $1.3 \mathrm{~g}$ iodine and $3 \mathrm{~g}$ potassium iodide were taken into a volumetric flask and $100 \mathrm{~mL}$ DW was added. Prepared Wagner's reagent (2-3 drops) was added to $1 \mathrm{~mL}$ of the plant extract in a test tube. The formation of red or brown precipitate indicated the presence of alkaloids.

\section{Test for flavonoids}

Diluted $\mathrm{NaOH}$ (2-3 drops) was added to $1 \mathrm{~mL}$ of the plant extract. The observation of intensed yellow colour in the test tube changed to colourless with the addition of few drops of diluted acid indicated the presence of flavonoids. 


\section{Test for saponins (Foam test)}

Water was added to the plant extract 1:1 (v/v) followed by heating for $5 \mathrm{~min}$. The appearance of froth indicated the presence of saponins.

\section{Test for steroids (Salkowski test)}

Chloroform and conc. $\mathrm{H}_{2} \mathrm{SO}_{4} 1: 1(\mathrm{v} / \mathrm{v})$ were added into $2 \mathrm{~mL}$ of the plant extract by the sides of the test tube. The formation of a reddish-brown ring at the junction indicated the presence of steroids.

\section{Test for tannins (Braymer's test)}

Two $\mathrm{mL}$ of water and $5 \% \mathrm{FeCl}_{3}$ (2-3 drops) were added to $2 \mathrm{~mL}$ of the plant extract. The formation of a green precipitate indicated the presence of tannins.

\section{Test for terpenoids}

Two $\mathrm{mL}$ of acetic anhydride and conc. $\mathrm{H}_{2} \mathrm{SO}_{4}$ (2-3 drops) were added to $2 \mathrm{~mL}$ of the plant extract. The red colour formation indicated the presence of terpenoids.

\section{Test for coumarins}

$10 \%(\mathrm{v} / \mathrm{v}) \mathrm{NaOH} 3 \mathrm{~mL}$ was added to $2 \mathrm{~mL}$ of the plant extract. The formation of a yellow colour indicated the presence of coumarins.

\section{Test for anthocyanins}

Two $\mathrm{mL} \mathrm{HCl}(2 \mathrm{~N})$ and ammonia (few drops) were added to the $2 \mathrm{~mL}$ plant extract. The pink-red colour turned into a blue-violet colour indicated the presence of anthocyanins.

\section{Test for leucoanthocyanins}

Isoamyl alcohol and the plant extract were mixed in 1:1 (v/v) ratio. The appearance of a reddish upper layer indicated the presence of leucoanthocyanins.

\section{Determination of Total Phenolic Content}

Total phenolic content (TPC) was determined according to the Folin Ciocalteu procedure by using gallic acid as the standard for forty-five crude extracts from fifteen selected plant parts. Sample of $1 \mathrm{~mL}$ plant

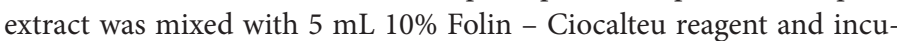
bated at room temperature. After $5 \mathrm{~min}, 4 \mathrm{~mL}$ of $7.5 \%(\mathrm{v} / \mathrm{V})$ sodium carbonate was added. The mixture was kept for $1 \mathrm{~h}$ at room temperature and the absorbance of each sample was measured at $765 \mathrm{~nm}$ using Spectro UV-VIS Double Beam PC Scanning Spectrophotometer (UVD 2960, LABOMED.INC, USA). The TPC values were calculated using gallic acid calibration curve within the range of $0.02-0.10 \mathrm{mg} / \mathrm{mL}$ and expressed as gallic acid equivalents (GAE) $\mathrm{mg} / \mathrm{g}$ of extract weight. Samples were analyzed in triplicate. ${ }^{[12]}$

\section{Determination of Total Flavonoid Content}

Total flavonoid content (TFC) was determined using Aluminum Chloride Colourimetric Assay using quercetin as the standard for forty-five crude extracts from fifteen selected plant parts. TFC was expressed as quercetin equivalents (QE) $\mathrm{mg} / \mathrm{g}$ of extract weight and samples were analyzed in triplicate as previously described. ${ }^{[13]}$ Briefly, each sample $(1 \mathrm{~mL})$ was mixed with $4 \mathrm{~mL}$ of DW and subsequently with $0.3 \mathrm{~mL}$ of a $5 \% \mathrm{NaNO}_{2}$. After $5 \mathrm{~min}, 0.3 \mathrm{~mL}$ of $10 \% \mathrm{AlCl}_{3}$ was added. At the $6^{\text {th }} \mathrm{min}, 2 \mathrm{~mL}$ of 1.0 $\mathrm{M} \mathrm{NaOH}$ was added to neutralize, followed by an addition DW up to $10 \mathrm{~mL}$ level for further dilution. The absorbance of each sample was measured at $510 \mathrm{~nm}$ using Spectro UV-VIS Double Beam PC Scanning Spectrophotometer (UVD 2960, LABOMED.INC, USA). The TFC values were calculated using the quercetin calibration curve ranging from $100-1800 \mu \mathrm{g} / \mathrm{mL}$.

\section{Cell viability assay}

3T3-L1 preadipocytes were obtained from the American Type Culture Collection (Manassas, VA). Cell viability was determined by the colourimetric method of 3-(4, 5-dimethylthiazol-2-yl)-5-(3-carboxymethoxyphenyl)2-(4-sulfophenyl)-2H-tetrazolium (MTS) assay. The yellow MTS solution is reduced to purple formazan in the mitochondria of living cells. This reduction takes place only when mitochondrial reductase enzymes are active, and therefore conversion can be directly related to the number of viable (living) cells. Briefly, cells were seeded in 96-well plates at a density of 5,000 cells/well. After 2-day post-confluence, 3T3-L1 preadipocytes were stimulated on day 0 (D0) for $72 \mathrm{~h}$ (D3) in differentiation activation medium containing DMEM, $10 \%$ FBS with an inducer $(1 \mu \mathrm{g} / \mathrm{mL}$ insulin, $0.25 \mu \mathrm{M}$ dexamethasone and $40 \mu \mathrm{M}$ troglitazone) as described elsewhere ${ }^{[14]}$ together with different concentrations of water extract (WE) $(125,250$ and $500 \mu \mathrm{g} / \mathrm{mL}$ ) or ethanol extracts (EE) $(25,50,100$ and $200 \mu \mathrm{g} / \mathrm{mL})$. On D3, the medium was changed to maintenance medium (DMEM with $10 \%$ FBS and $1 \mu \mathrm{g} / \mathrm{mL}$ insulin) along with the treatment for two more days (D5). At the end of D5, the medium was replenished by adding $100 \mu \mathrm{L}$ fresh $10 \%$ FBS/DMEM together with $20 \mu \mathrm{L}$ MTS solution. Subsequently, the cells were incubated for $40 \mathrm{~min}$ at $37^{\circ} \mathrm{C}$. The absorbance was measured spectrophotometrically at $490 \mathrm{~nm}$ using a microplate reader starting from $0 \mathrm{~min}$, up to $40 \mathrm{~min}$ at $5 \mathrm{~min}$ interval points (Infinite M200Pro, Tecan Wako, Japan).

\section{Oil Red O Staining of Adipocytes}

At the end of the treatment period, neutral lipids was measured using ORO staining. Lipid accumulation of differentiated adipocytes were fixed with $4 \%$ paraformaldehyde for $15 \mathrm{~min}$. After removing the media, cells were washed three times with PBS and stained with $60 \%$ ORO solution for $20 \mathrm{~min}$. The lipid accumulation in cells was visualized and captured under a C2 confocal laser-scanning microscope (Nikon, Tokyo, Japan) at 10X (scale bar:100 $\mu \mathrm{m}$ ) magnification. For the quantification of lipid accumulation, stained oil droplets in 3T3-L1 cells were extracted with $100 \%$ isopropyl alcohol for $10 \mathrm{~min}$. The absorbance of the extracted dye was measured at $520 \mathrm{~nm}$ (Infinite M200Pro, Tecan Wako, Japan).

\section{Statistical Analyses}

The results were expressed as the means \pm standard deviation of each group. The statistical significance between the means of different solvents of each plant part was determined by one-way analysis of variance (ANOVA) followed by Tukey comparison test and the differences between the mean values of the control and treatment groups were analyzed by Dunnett's test. The level of significance was uniformly set at $p<0.05$.

\section{RESULTS}

\section{Phytochemical screening}

Qualitative biochemical estimations were conducted to detect different bioactive compounds in different solvent extracts. The results of all sought bioactive substances are tabulated in Table 2 .

The results of three different crude extracts of tested medicinal plants confirmed the presence of flavonoids, tannins, terpenoids, alkaloids, steroids, anthocyanins and coumarins. However, saponins and leucoanthocyanins were not found in any of the extracted solvents. All tested phytochemicals except saponins and leucoanthocyanins were present in the WE and EE, while alkaloids, terpenoids, flavonoids and coumarins were the only metabolites found in the hexane extract (HE).

\section{Total phenolic content of plant extracts}

A quantitative study was further performed to quantify the available phenol content in different plant extracts. The results of TPC related to each extracting solvent are presented in Table 3. Nine out of fifteen 


\begin{tabular}{|c|c|c|c|c|c|c|c|c|c|c|c|c|}
\hline 울 & $\begin{array}{l}\stackrel{0}{E} \\
\frac{\pi}{2} \\
\stackrel{+}{c} \\
\frac{\pi}{0}\end{array}$ & 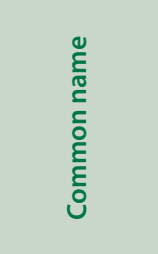 & 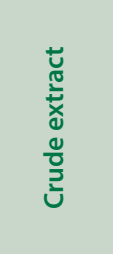 & 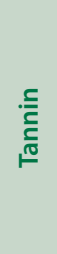 & $\begin{array}{l}\frac{n}{0} \\
0 \\
0 \\
\frac{\pi}{4}\end{array}$ & $\begin{array}{l}\frac{n}{0} \\
\frac{0}{0} \\
\frac{0}{2} \\
\frac{0}{0}\end{array}$ & 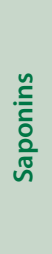 & $\begin{array}{l}\frac{n}{0} \\
\frac{0}{2} \\
\dot{\nu}\end{array}$ & $\begin{array}{l}. \frac{n}{\frac{n}{J}} \\
\frac{\text { हn }}{5} \\
0\end{array}$ & $\begin{array}{l}\frac{n}{0} \\
\frac{0}{0} \\
\frac{0}{x}\end{array}$ & 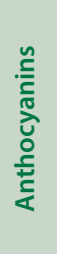 & 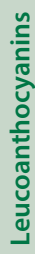 \\
\hline \multirow[t]{3}{*}{1} & \multirow[t]{3}{*}{ Aerva lanata } & \multirow[t]{3}{*}{ Polpala } & Ethanol & + & ++ & - & - & - & - & + & - & - \\
\hline & & & Hexane & - & - & - & - & - & - & + & - & - \\
\hline & & & Water & ++ & - & - & - & - & ++ & ++ & - & - \\
\hline \multirow[t]{3}{*}{2} & \multirow{3}{*}{$\begin{array}{c}\text { Averrhoa } \\
\text { bilimbi } \\
\text { Flowers }\end{array}$} & \multirow[t]{3}{*}{ Bilin } & Ethanol & ++ & - & ++ & - & ++ & - & ++ & + & - \\
\hline & & & Hexane & - & + & + & - & - & - & + & - & - \\
\hline & & & Water & ++ & + & ++ & - & ++ & + & + & + & - \\
\hline \multirow[t]{3}{*}{3} & \multirow{3}{*}{$\begin{array}{c}\text { Averrhoa } \\
\text { bilimbi } \\
\text { Leaves }\end{array}$} & \multirow[t]{3}{*}{ Bilin } & Ethanol & + & - & - & - & - & - & ++ & - & - \\
\hline & & & Hexane & - & - & - & - & - & + & + & - & - \\
\hline & & & Water & ++ & + & - & - & + & ++ & + & + & - \\
\hline \multirow[t]{3}{*}{4} & \multirow{3}{*}{$\begin{array}{c}\text { Murraya } \\
\text { koenigii }\end{array}$} & \multirow[t]{3}{*}{ Karapincha } & Ethanol & + & - & - & - & - & - & + & - & - \\
\hline & & & Hexane & - & - & - & - & - & - & + & - & - \\
\hline & & & Water & ++ & + & - & - & - & + & ++ & - & - \\
\hline \multirow[t]{3}{*}{5} & \multirow{3}{*}{$\begin{array}{c}\text { Alysicarpus } \\
\text { vaginalis }\end{array}$} & \multirow[t]{3}{*}{ Aswenna } & Ethanol & + & - & - & - & - & - & + & - & - \\
\hline & & & Hexane & - & - & - & - & - & - & + & - & - \\
\hline & & & Water & ++ & - & - & - & - & + & + & - & - \\
\hline \multirow[t]{3}{*}{6} & \multirow{3}{*}{$\begin{array}{l}\text { Hemidesmus } \\
\quad \text { indicus }\end{array}$} & \multirow[t]{3}{*}{ Iramusu } & Ethanol & + & + & - & - & - & - & ++ & - & - \\
\hline & & & Hexane & - & - & - & - & - & - & + & - & - \\
\hline & & & Water & ++ & + & - & - & - & ++ & ++ & - & - \\
\hline \multirow[t]{3}{*}{7} & \multirow{3}{*}{$\begin{array}{l}\text { Ipomoea } \\
\text { aquatica }\end{array}$} & Kankun & Ethanol & + & - & - & - & - & - & ++ & - & - \\
\hline & & & Hexane & - & - & - & - & - & - & + & - & - \\
\hline & & & Water & ++ & + & - & - & - & ++ & + & - & - \\
\hline 8 & Tinospora & Rasakinda & Ethanol & - & + & - & - & - & + & ++ & - & - \\
\hline & cordifolia & & Hexane & - & - & - & - & - & - & + & - & - \\
\hline & & & Water & + & - & - & - & - & ++ & ++ & - & - \\
\hline 9 & Cassia & Ranawara & Ethanol & - & + & ++ & - & ++ & - & ++ & - & - \\
\hline & auriculata & & Hexane & - & - & - & - & - & - & + & - & - \\
\hline & & & Water & ++ & - & ++ & - & ++ & ++ & + & - & - \\
\hline 10 & Asparagus & Hathavariya & Ethanol & + & - & - & - & - & - & ++ & - & - \\
\hline & falcatus & & Hexane & - & - & - & - & - & - & + & - & - \\
\hline & & & Water & ++ & - & - & - & - & - & ++ & - & - \\
\hline 11 & Centella & Gotukola & Ethanol & - & - & - & - & - & - & ++ & - & - \\
\hline & asiatica & & Hexane & - & - & - & - & - & - & + & - & - \\
\hline & & & Water & + & ++ & - & - & - & ++ & ++ & - & - \\
\hline 12 & Justicia & Adhathoda & Ethanol & + & - & - & - & - & - & + & - & - \\
\hline & adhathoda & & Hexane & - & - & - & - & - & - & + & - & - \\
\hline & & & Water & - & + & + & - & + & ++ & + & + & - \\
\hline 13 & Cyperus & Kalanduru & Ethanol & - & + & + & - & - & + & ++ & - & - \\
\hline & rotundus & & Hexane & - & - & - & - & - & - & + & - & - \\
\hline & & & Water & + & + & ++ & - & + & + & ++ & - & - \\
\hline 14 & Aegle & Beli & Ethanol & - & + & - & - & + & + & ++ & - & - \\
\hline & marmelos & & Hexane & - & - & - & - & - & - & + & - & - \\
\hline & & & Water & ++ & - & + & - & + & + & ++ & - & - \\
\hline 15 & Salacia & Kothala & Ethanol & - & + & ++ & - & + & - & ++ & - & - \\
\hline & reticulata & himbutu & Hexane & - & - & + & - & - & - & + & - & - \\
\hline & & & Water & ++ & + & - & - & + & ++ & + & - & - \\
\hline
\end{tabular}

${ }^{++}$Present in high amount; ${ }^{+}$Present in low amount; - Absent 
Silva, et al.: Phytochemicals and Bioassays of Herbal Plants in Sri Lanka

Table 3: Quantification of phenolic contents of the crude extracts.

\begin{tabular}{ccccc}
\hline $\begin{array}{c}\text { Sample } \\
\text { No }\end{array}$ & Plant Name & WE & EE & HE \\
\hline 1 & Aerva lanata & $3.97 \pm 0.00^{\mathrm{a}}$ & $1.13 \pm 0.00^{\mathrm{b}}$ & $1.57 \pm 0.01^{\mathrm{c}}$ \\
2 & Averrhoa bilimbi $(\mathrm{F})$ & $4.61 \pm 0.01^{\mathrm{a}}$ & $2.02 \pm 0.00^{\mathrm{b}}$ & $1.74 \pm 0.00^{\mathrm{c}}$ \\
3 & Averrhoa bilimbi $(\mathrm{L})$ & $7.78 \pm 0.00^{\mathrm{a}}$ & $1.64 \pm 0.00^{\mathrm{b}}$ & $0.08 \pm 0.00^{\mathrm{c}}$ \\
4 & Murraya koenigii & $1.66 \pm 0.00^{\mathrm{a}}$ & $1.95 \pm 0.00^{\mathrm{b}}$ & $0.96 \pm 0.00^{\mathrm{c}}$ \\
5 & Alysicarpus vaginalis & $5.03 \pm 0.00^{\mathrm{a}}$ & $1.85 \pm 0.00^{\mathrm{b}}$ & $2.45 \pm 0.01^{\mathrm{c}}$ \\
6 & Hemidesmus indicus & $6.90 \pm 0.01^{\mathrm{a}}$ & $5.22 \pm 0.00^{\mathrm{b}}$ & $2.49 \pm 0.01^{\mathrm{c}}$ \\
7 & Ipomoea aquatica & $4.66 \pm 0.00^{\mathrm{a}}$ & $1.61 \pm 0.00^{\mathrm{b}}$ & $4.31 \pm 0.02^{\mathrm{c}}$ \\
8 & Tinospora cordifolia & $3.82 \pm 0.00^{\mathrm{a}}$ & $2.50 \pm 0.01^{\mathrm{b}}$ & $3.98 \pm 0.01^{\mathrm{c}}$ \\
9 & Cassia auriculata & $4.68 \pm 0.00^{\mathrm{a}}$ & $7.73 \pm 0.00^{\mathrm{b}}$ & $4.76 \pm 0.03^{\mathrm{c}}$ \\
10 & Asparagus falcatus & $3.91 \pm 0.00^{\mathrm{a}}$ & $1.77 \pm 0.00^{\mathrm{b}}$ & $0.57 \pm 0.00^{\mathrm{c}}$ \\
11 & Centella asiatica & $1.41 \pm 0.00^{\mathrm{a}}$ & $1.61 \pm 0.00^{\mathrm{b}}$ & $0.99 \pm 0.00^{\mathrm{c}}$ \\
12 & Justicia adhathoda & $7.58 \pm 0.02^{\mathrm{a}}$ & $0.94 \pm 0.00^{\mathrm{b}}$ & $0.06 \pm 0.00^{\mathrm{c}}$ \\
13 & Cyperus rotundus & $2.25 \pm 0.00^{\mathrm{a}}$ & $1.78 \pm 0.00^{\mathrm{b}}$ & $3.44 \pm 0.01^{\mathrm{c}}$ \\
14 & Aegle marmelos & $1.41 \pm 0.00^{\mathrm{a}}$ & $0.92 \pm 0.00^{\mathrm{b}}$ & $1.89 \pm 0.01^{\mathrm{c}}$ \\
15 & Salacia reticulata & $7.40 \pm 0.00^{\mathrm{a}}$ & $5.13 \pm 0.00^{\mathrm{b}}$ & $2.03 \pm 0.00^{\mathrm{c}}$ \\
\hline
\end{tabular}

Similar results were obtained in three independent experiments. All the values were represented as mean \pm standard deviation $(n=3)$, values that do not share a letter are significantly different $(p<0.05)$.

plant parts used in this study were endowed with higher phenolic content in the presence of DW. The WE of A. bilimbi (leaves) demonstrated the highest TPC with $7.775 \pm 0.000 \mathrm{mg} \mathrm{GAE} / \mathrm{g}$ extract followed by the EE of C. auriculata with $7.731 \pm 0.000 \mathrm{mg} \mathrm{GAE} / \mathrm{g}$ extract, respectively. The WE of J. adhathoda showed $7.583 \pm 0.019 \mathrm{mg} \mathrm{GAE} / \mathrm{g}$ extract, with only 0.060 $\pm 0.001 \mathrm{mg} \mathrm{GAE} / \mathrm{g}$ extract found in the HE of the same plant. Moreover, the WE of both $S$. reticulata (7.402 $\pm 0.000 \mathrm{mg} \mathrm{GAE} / \mathrm{g}$ extract) and $H$. indicus (6.901 $\pm 0.005 \mathrm{mg} \mathrm{GAE} / \mathrm{g}$ extract) showed higher levels of $\mathrm{TPC}$ and the $\mathrm{EE}$ of $H$. indicus (5.219 $\pm 0.000 \mathrm{mg} \mathrm{GAE} / \mathrm{g}$ extract) was the second-highest to possess phenolic compounds from the rest of the EE of different plant parts. When hexane was used as an extraction solvent, highest levels of TPC were observed for C. auriculata $(4.761 \pm 0.026 \mathrm{mg}$ GAE/g extract), I. aquatica (4.307 $\pm 0.015 \mathrm{mg}$ GAE/g extract), and T. cordifolia (3.977 $\pm 0.005 \mathrm{mg}$ GAE/g extract). Compared with ethanol and DW, hexane was a better solvent to extract higher phenolic content $(p<0.05)$ from $T$. cordifolia (3.977 $\pm 0.005 \mathrm{mg} \mathrm{GAE} / \mathrm{g}$ extract), C. rotundus (3.440 $\pm 0.013 \mathrm{mg} \mathrm{GAE} / \mathrm{g}$ extract), and A. marmelos $(1.891 \pm 0.010$ $\mathrm{mg}$ GAE/g extract).

\section{Total flavonoid content of plant extracts}

The content of flavonoids in plant extracts was determined using quercetin as the standard. Among the three solvents, the flavonoid content of water and ethanol extracts was higher than that of the HE (Table 4). The maximum flavonoid content was observed in the WE of $H$. indicus (146.225 $\pm 0.188 \mathrm{mg} \mathrm{QE} / \mathrm{g}$ extract), while the least was found in the HE of J. adhathoda $(2.746 \pm 0.0360 \mathrm{mg} \mathrm{QE} / \mathrm{g}$ extract). The WE of $A$. marmelos (114.350 $\pm 0.118 \mathrm{mg} \mathrm{QE} / \mathrm{g}$ extract) and $M$. koenigii $(81.142 \pm 0.072 \mathrm{mg}$ QE/g extract) showed second and third highest levels, respectively, while H. indicus (119.600 $\pm 0.000 \mathrm{mg} \mathrm{QE} / \mathrm{g}$ extract) and S. reticulata (89.225 \pm $0.000 \mathrm{mg} \mathrm{QE} / \mathrm{g}$ extract) showed the highest levels of TFC extracted using ethanol. Although $n$-hexane was the least flavonoid extractable solvent, it managed to extract $23.204 \pm 0.036 \mathrm{mg} \mathrm{QE} / \mathrm{g}$ extract from $H$. indicus, marking the highest extracted flavonoid content compared to the HE of other plant parts.
Table 4: Quantification of flavonoid contents of the crude extracts.

\begin{tabular}{ccccc}
\hline $\begin{array}{c}\text { Sample } \\
\text { No }\end{array}$ & Plant Name & WE & EE & HE \\
\hline 1 & Aerva lanata & $15.98 \pm 0.11^{\mathrm{a}}$ & $49.52 \pm 0.04^{\mathrm{b}}$ & $15.12 \pm 0.04^{\mathrm{c}}$ \\
2 & Averrhoa bilimbi (F) & $30.23 \pm 0.06^{\mathrm{a}}$ & $22.08 \pm 0.10^{\mathrm{b}}$ & $5.33 \pm 0.07^{\mathrm{c}}$ \\
3 & Averrhoa bilimbi (L) & $74.39 \pm 0.07^{\mathrm{a}}$ & $53.48 \pm 0.00^{\mathrm{b}}$ & $5.95 \pm 0.07^{\mathrm{c}}$ \\
4 & Murraya koenigii & $81.14 \pm 0.07^{\mathrm{a}}$ & $59.31 \pm 0.14^{\mathrm{b}}$ & $11.56 \pm 0.10^{\mathrm{c}}$ \\
5 & Alysicarpus vaginalis & $16.66 \pm 0.00^{\mathrm{a}}$ & $42.10 \pm 0.00^{\mathrm{b}}$ & $18.58 \pm 0.04^{\mathrm{c}}$ \\
6 & Hemidesmus indicus & $146.23 \pm 0.19^{\mathrm{a}}$ & $119.60 \pm 0.00^{\mathrm{b}}$ & $23.20 \pm 0.04^{\mathrm{c}}$ \\
7 & Ipomoea aquatica & $50.98 \pm 0.11^{\mathrm{a}}$ & $51.12 \pm 0.04^{\mathrm{a}}$ & $10.68 \pm 0.04^{\mathrm{b}}$ \\
8 & Tinospora cordifolia & $6.25 \pm 0.04^{\mathrm{a}}$ & $26.29 \pm 0.00^{\mathrm{b}}$ & $6.39 \pm 0.04^{\mathrm{c}}$ \\
9 & Cassia auriculata & $44.79 \pm 0.00^{\mathrm{a}}$ & $84.10 \pm 0.00^{\mathrm{b}}$ & $15.73 \pm 0.11^{\mathrm{c}}$ \\
10 & Asparagus falcatus & $18.79 \pm 0.00^{\mathrm{a}}$ & $47.60 \pm 0.00^{\mathrm{b}}$ & $7.77 \pm 0.04^{\mathrm{c}}$ \\
11 & Centella asiatica & $73.02 \pm 0.19^{\mathrm{a}}$ & $47.27 \pm 0.14^{\mathrm{b}}$ & $5.62 \pm 0.07^{\mathrm{c}}$ \\
12 & Justicia adhathoda & $46.60 \pm 0.06^{\mathrm{a}}$ & $59.06 \pm 0.07^{\mathrm{b}}$ & $2.75 \pm 0.04^{\mathrm{c}}$ \\
13 & Cyperus rotundus & $36.98 \pm 0.00^{\mathrm{a}}$ & $12.60 \pm 0.00^{\mathrm{b}}$ & $10.91 \pm 0.11^{\mathrm{c}}$ \\
14 & Aegle marmelos & $114.35 \pm 0.19^{\mathrm{a}}$ & $51.16 \pm 0.17^{\mathrm{b}}$ & $12.10 \pm 0.06^{\mathrm{c}}$ \\
15 & Salacia reticulata & $59.77 \pm 0.14^{\mathrm{a}}$ & $89.23 \pm 0.00^{\mathrm{b}}$ & $5.06 \pm 0.07^{\mathrm{c}}$ \\
\hline
\end{tabular}

Similar results were obtained in three independent experiments. All the values were represented as mean \pm standard deviation $(\mathrm{n}=3)$, values that do not share a letter are significantly different $(p<0.05)$.

\section{Cytotoxicity assay for selecting potential plant extracts}

With the understanding of the effectiveness of water and ethanol as solvents possessing better extraction yields, we were intrigued to evaluate the potential anti-adiposity activity of the WE and EE of plants. In this context, it was mandatory to understand the cytotoxic levels of each extract towards the adipogenic cell model, 3T3-L1. Thus, we conducted the MTS assay to determine the cytotoxic potential of the WE and EE. As shown in Figure 1, nine out of fifteen plant parts used in this study showed almost $100 \%$ cell viability at $500 \mu \mathrm{g} / \mathrm{mL}$ in the presence of the WE. As illustrated in Figure $2 \mathrm{a}$ and b, EE of A. lanata, A. vaginalis, T. cordifolia, C. asiatica, J. adhathoda, and C. rotundus showed no toxicity at a concentration of $100 \mu \mathrm{g} / \mathrm{mL}$, while $A$. bilimbi flowers and leaves, $M$. koenigii, $H$. indicus, and $I$. aquatica were limited to a maximum concentration of $50 \mu \mathrm{g} / \mathrm{mL}$ to maintain $100 \%$ cell viability. Both A. marmelos and $S$. reticulata were toxic to adipocytes in the presence of 50 and $100 \mu \mathrm{g} / \mathrm{mL}$ of EE, however, the WE of S. reticulata was a better candidate to be tested against adipogenesis as it showed stronger cell viability at $250 \mu \mathrm{g} / \mathrm{mL}$.

\section{Screening for potential plant extracts with anti-adipogenic properties}

Depending on the experimental evidence of cell viability tests, different concentrations of the WE and EE of all plants were selected to study their effect on lipid accumulation. The 3T3-L1 preadipocytes were treated with various doses of WE or EE for 5 days, and intracellular lipid accumulation was examined by lipid droplets stained with ORO as an indicator of the degree of adipogenesis. As shown in Figure 3, none of the aqueous extracts showed inhibition of lipid accumulation, rather significantly increased adipogenesis due to A. lanata, A. bilimbi, M. koenigii, A. vaginalis, $H$. indicus, I. aquatica, T. cordifolia, C. auriculata. Alternatively, the EE of most plants effectively attenuated the triglyceride (TG) content in adipocytes. The ORO images (Figure 4 a) and the quantification results (Figure $4 \mathrm{~b}$ ) showed that the EE of $J$. adhathoda inhibited lipid accumulation by $88.31 \%$, which is the highest inhibition demonstrated, while A. lanata and C. rotundus suppressed adiposity $(p<0.05)$ by 74.65 and $74.04 \%$, respectively. $M$. koenigii and $H$. indicus suppressed lipid 


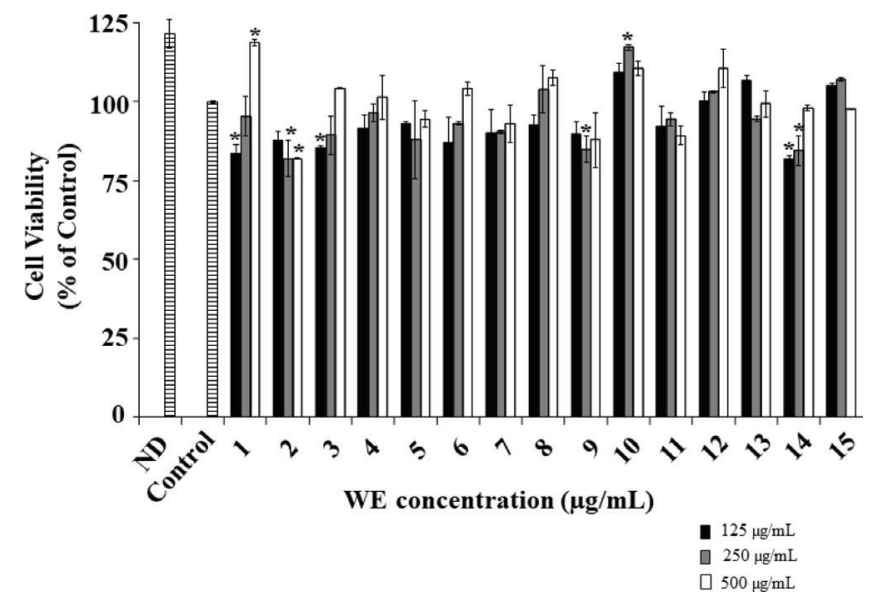

Figure 1: The cytotoxic potential of different water extracts (WE) under different concentrations $(125,250,500 \mu \mathrm{g} / \mathrm{mL})$. Cell viability was determined by MTS assay. All data are shown as mean \pm standard deviation of three independent experiments. Significant difference was identified at ${ }^{*} p<0.05$ compared to the control group.

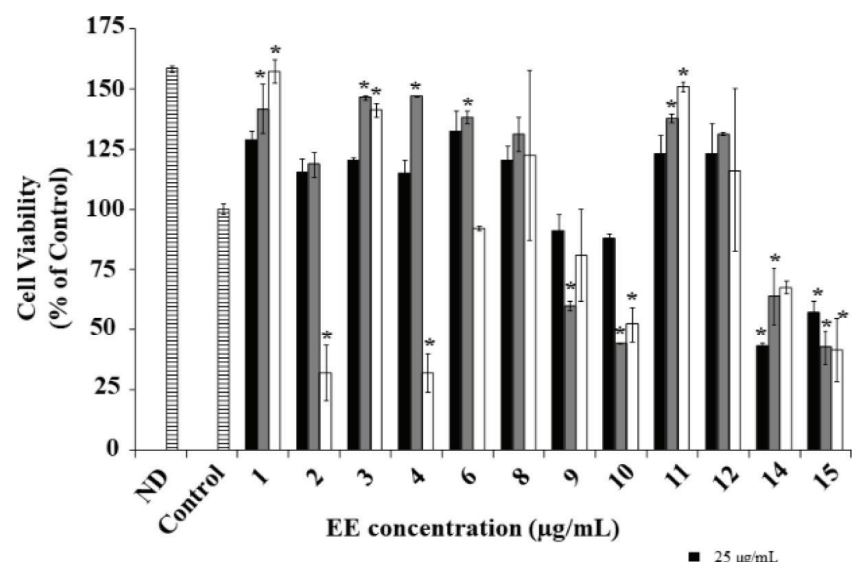

ㅁ $25 \mu \mathrm{gg} / \mathrm{mL}$ ㅁ $100 \mu \sigma / \mathrm{mL}$

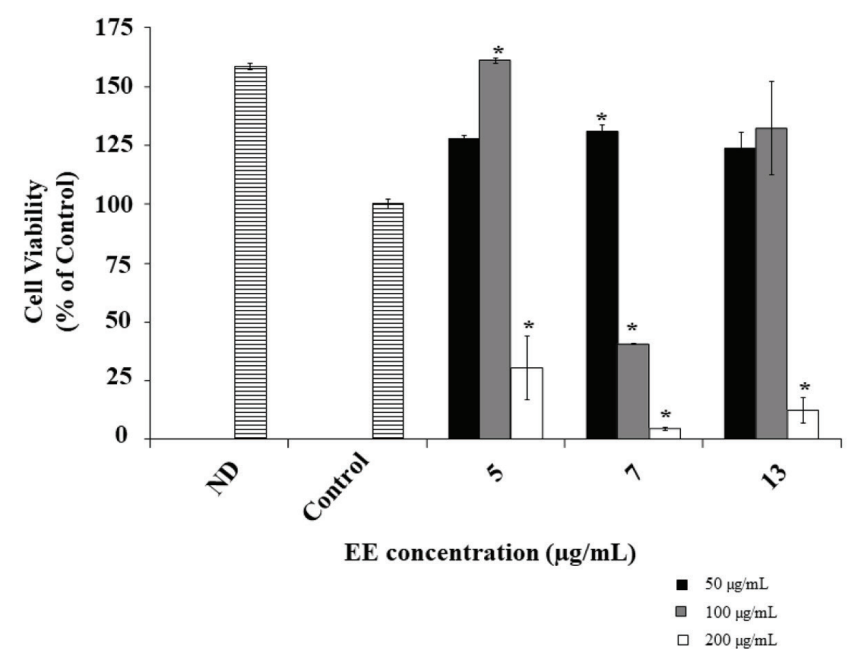

Figure 2: The cytotoxic potential of different ethanol extracts (EE). 3T3-L1 cell viability was determined by MTS assay. (a) Cells were exposed to 25,50 , $100 \mu \mathrm{g} / \mathrm{mL}$ EE. (b) Cells were exposed to 50, 100, $200 \mu \mathrm{g} / \mathrm{mL}$ EE. All data are shown as mean \pm standard deviation of three independent experiments. Significant difference was identified at ${ }^{*} p<0.05$ compared to the control group.

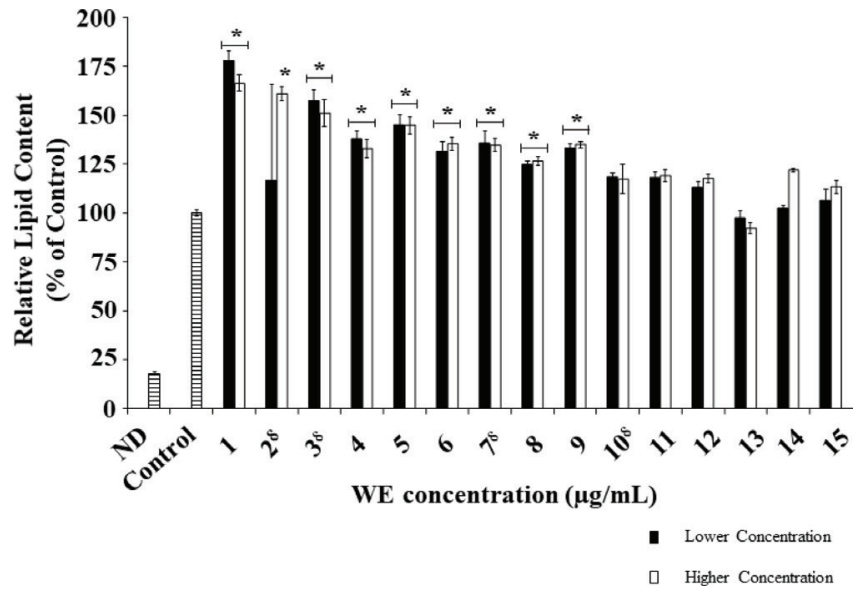

Figure 3: The effect of the water extracts (WE) on lipid accumulation in 3T3-L1 preadipocytes under lower concentrations $(25 \mu \mathrm{g} / \mathrm{mL}$ for $\delta$ marked samples and $50 \mu \mathrm{g} / \mathrm{mL}$ for rest of all) and higher concentrations $(50 \mu \mathrm{g} / \mathrm{mL}$ for $\delta$ marked samples and $100 \mu \mathrm{g} / \mathrm{mL}$ for rest of the samples). All data are shown as mean \pm standard deviation of three independent experiments. Significant difference was identified at ${ }^{*} p<0.05$ compared to the control group.
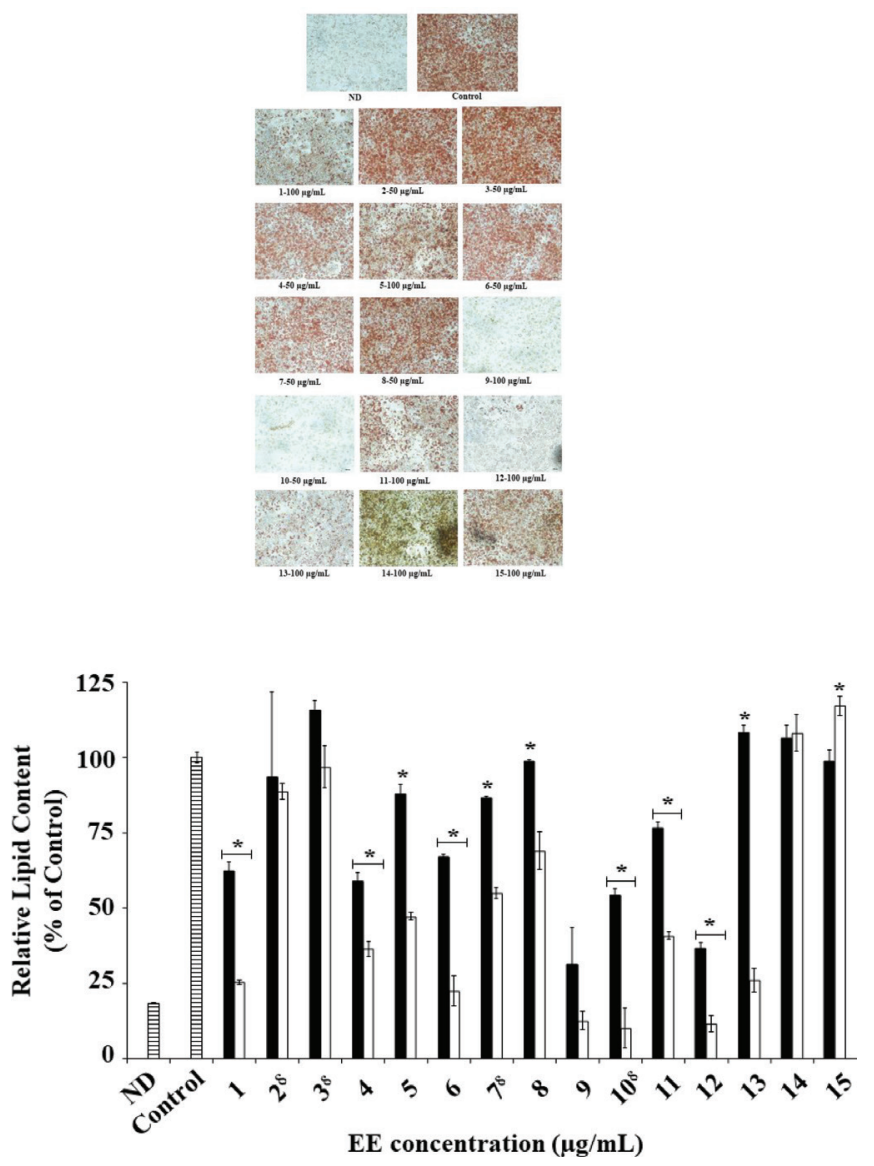

Figure 4: Effect of the ethanol extract (EE) on lipid accumulation in 3T3-L1 preadipocytes. Cells were treated with various doses of EE. After 5 days, cells were fixed and stained with Oil red $O$. (a) Images of representative cells were captured using a C2 confocal laser-scanning microscope with 10X magnification. (b) Cells were treated with EE lower concentrations $(25 \mu \mathrm{g} / \mathrm{mL}$ for $\delta$ marked samples and $50 \mu \mathrm{g} / \mathrm{mL}$ for rest of all) and higher concentrations $(50 \mu \mathrm{g} / \mathrm{mL}$ for $\delta$ marked samples and $100 \mu \mathrm{g} / \mathrm{mL}$ for rest of all). All data are shown as mean \pm standard deviation of three independent experiments. Significant difference was identified at ${ }^{*} p<0.05$ compared to the control group. 
accumulation $(p<0.05)$ in the presence of both concentrations, 50 and $100 \mu \mathrm{g} / \mathrm{mL}$, however, due to the poor cell viability at $100 \mu \mathrm{g} / \mathrm{mL}$, the suppression in TG content due to $50 \mu \mathrm{g} / \mathrm{mL}$ EE was considered as potential anti-adipogenic extracts. Moreover, the $\mathrm{EE}$ of $A$. vaginalis and C. asiatica attenuated lipid accumulation by $>50 \%(p<0.05)$, whereas the EE of T. cordifolia was able to reduce the TG content by $31.02 \%$. Both the $\mathrm{EE}$ of $A$. marmelos and $S$. reticulata showed no anti-adipogenic activity in the presence of the tested concentrations.

\section{DISCUSSION}

Crude plant extracts are generally a mixture of active and non-active compounds. For the acceptance of medicinal plants into scientific medicine, it is necessary that their effectiveness and safety be evaluated and confirmed through active ingredient testing. To maximize the extractive capability of phenolic and flavonoid components from plant material is considerably dependent on the type of solvent. This study was carried out to compare the efficiency of different extracting solvents to elute different bioactive compounds, identify the cytotoxicity potential and anti-obesity activity of commonly used medicinal plants in Sri Lanka.

The present study used three types of solvents with respective polarity in descending order, DW $>$ ethanol $(99.9 \%)>n$-hexane in the process of extraction of each plant sample to obtain forty-five extracts altogether. Ethanol and methanol as polar solvents are frequently used for the extraction of phenolic compounds, ${ }^{[15-20]}$ whereas several studies have categorized phenols as moderate polar compounds. ${ }^{[21]}$ It has also been reported that phenolic compounds and flavonoids are polar compounds and showed higher solubility in 50\% hydroethanolic extract than in water extract of guava leaves while possessing higher antioxidant properties. ${ }^{[22]}$ Nevertheless, we demonstrated that DW was the most efficient solvent for extracting phenolic compounds from these medicinal plants while $n$-hexane was merely capable of extracting minute levels of phenolic and flavonoid constituents with a hydrophobic nature. This result is consistent with previous reports showing that the phenolic compound content of water extract was higher than in pure ethanol or hexane. ${ }^{[23,24]}$

Phenolic compounds are abundant in most medicinal plants and constitute an essential part of the human diet due to their antioxidant and many other beneficial properties on health. We demonstrated that DW extracted the highest phenolic compounds and flavonoid content obtained from A. bilimbi leaves when compared with other plants. It has been previously demonstrated that the EE of $A$. bilimbi leaves possessed hypoglycemic, hypolipidemic, and anti-lipid peroxidative properties, ${ }^{[25]}$ and the aqueous extract of its fruit attenuated the blood glucose level and oxidative stress in streptozotocin-induced diabetic rats. ${ }^{[2]}$ The aqueous and chloroform extracts of $A$. bilimbi leaves and fruits $(100 \mathrm{mg} / \mathrm{mL})$ showed a positive antibacterial activity, ${ }^{[27]}$ suggesting the type of secondary metabolites expected to be extracted for a specific activity depend on the extracting solvent. Further confirming this statement, we showed M. koenigii, and C. asiatica performing better when used ethanol to extract phenolic compounds and possessed lipid accumulation inhibition capacity while maintaining strong cell viability. However, in our study, M. koenigii showed a better flavonoid content when DW was used. $M$. koenigii is an essential ingredient of spices in Sri Lankan culinary and directly incorporated into boiling water or water-coconut milk mixtures, probably enabling the utilization of its higher flavonoid content for the benefit of the end-user. C. asiatica is a leafy vegetable, commonly found in Sri Lankan lunch-platter used for skin problems, wound healing and revitalizing brain cells and nerves for many decades ${ }^{[28,29]}$ and the ethanolic and methanolic extracts of C. asiatica had shown significant protection and lowered the blood glucose in vivo. ${ }^{[30]}$ Concomitantly, we showed that the EE of C. asiatica extracted the highest flavonoid content compared to other solvents, suggesting it as a potential natural antidiabetic therapeutic agent. Flavonoids are one of the major groups classified under phenolic compounds. According to several studies on flavonoids, flavones and catechins have been found as the most powerful flavonoids to act as antioxidants for protecting the body against reactive oxygen species. ${ }^{[31]}$ In the present investigation, $H$. indicus and $S$. reticulata showed the highest levels of TFC extracted using ethanol. Previously it has been found that the EE of $H$. indicus had a considerable low level of TFC, probably due to the difference in the extraction method and the use of the whole plant for their study. ${ }^{[32]}$ Interestingly, our study revealed for the first time the effectiveness of using water and ethanol as extracting solvents to obtain a higher amount of both phenolic compounds and flavonoid content from $H$. indicus leaves.

From this study, it was also postulated that hexane was an efficient solvent for T. cordifolia, C. rotundus and A. marmelos in extracting higher phenolic content, however, the only available phytoconstituent in the HE of the three plants were alkaloids. This confirmed the higher content of hydrophobic alkaloids present in the three plants. It is noteworthy that we showed hexane possessing the ability to extract phenolic compounds from I. aquatica 1.7-fold higher than using ethanol as a solvent contradicting with the high level of phenolic content identified in the EE of I. aquatica leaf and stem, ${ }^{[33]}$ probably due to the higher amount of the only phytoconstituent, alkaloids found in the HE of I. aquatica in our study. Alkaloids show hydrophilic properties under acidic conditions and hydrophobic under neutral and basic conditions give them unique properties of their usage in the medical industry. ${ }^{[34]}$ Previous studies provide sufficient evidence on phenolic compounds and alkaloids for the management of non-communicable diseases such as obesity and obesity-related complications. ${ }^{[35-37]}$ Concordantly, we demonstrated the presence of alkaloids in all extracts of tested plants, whereas the WE and EE showed the highest availability, suggesting their potential to be used for treating obesity as it was previously demonstrated that expression levels of adipocyte marker genes being significantly downregulated due to plant alkaloids. ${ }^{[38]}$ Notably, that some polyhydroxylated alkaloids have been isolated from the bark of Morus alba L. into methanol as the extracting solvent, which has been identified as anti-obesity and antidiabetic agents. ${ }^{[39,40]}$ The WE of Catharanthus roseus L. leaf showed antidiabetic and anticancer properties ${ }^{[41]}$ and belongs to the same family of $H$. indicus used in this study, which possessed a high concentration of alkaloids in both WE and EE.

There are ubiquitous studies that have shown a positive correlation between its phenolic and flavonoid content with the antioxidant capacity. ${ }^{[42,43]}$ Moreover, antioxidant activities have increased depending on the concentration of the water extract of plants further strengthening the correlation between the antioxidant capacity and phenolic content. ${ }^{[23,44]}$ However, no evidence between the phenolic content and anti-obesity properties from plant extracts has been documented. Thus, we were further intrigued to investigate the possible relationship between them, which may give scientists a clue of potential plants with anti-obesity properties during the initial screening of phytochemicals. In this context, we selected the WE and EE of the screened plant parts as they demonstrated the highest phenolic compounds and flavonoid content to be investigated against cytotoxicity and adipogenesis.

The cytotoxic study showed the possibility of using water as an extracting solvent for many plants used in this study, indicating its safety as Ayurvedic herbal mixtures at higher doses, however, the EE of different plants showed various doses that are considered as safe and possessed anti-adipogenic activity as an added advantage. Adipogenesis is a process involved with increased growth of adipocyte mass, adipocyte differentiation, and accumulation of lipid in adipocytes. The synthesis 
and storage of lipids, in the form of triglycerides is the primary function of adipocytes. Hence, inhibiting adipogenesis would be one of the best strategies for the management of obesity. Herbal extracts enriched with polyphenols, alkaloids, etc., possess potent anti-adipogenic and hypoglycemic activities. ${ }^{[45]}$ Our study results exhibited decreased lipid content in all EE, except for A. bilimbi leaves and flowers, C. auriculata, A. falcatus, A. marmelos, and S. reticulata. The EE of J. adhathoda demonstrated the highest attenuation in lipid accumulation, however, with poor extractable phenolic compounds into the EE (Table 3). On the other hand, J. adhathoda eluted most flavonoids into the EE when compared with other two solvents, corresponding to previous studies suggesting physiological effects of flavonoids in the prevention of atherosclerosis and other coronary heart diseases. ${ }^{[4]]}$ The EE of $C$. auriculata showed the secondhighest TPC and TFC, however, the extract was toxic to cells at a concentration low as $25 \mu \mathrm{g} / \mathrm{mL}$ averting the ability to measure its effectiveness against adipogenesis. Concordantly, we showed 87.51 and $89.91 \%$ TG suppression in the presence of $100 \mu \mathrm{g} / \mathrm{mL}$ C. auriculata and $50 \mu \mathrm{g} / \mathrm{mL}$ A. falcatus EE, respectively, due to cell apoptosis. C. auriculata, locally known as Ranawara is used as a treatment for urinary tract infection ${ }^{[47]}$ and previous evidence showed that $500 \mu \mathrm{g} / \mathrm{mL}$ EE of $A$. gonoclados root tubers having a-glucosidase inhibitory activity. ${ }^{[48]}$ However, these studies have not shown an optimization of cytotoxicity under different extracts or doses of the respective plants. It is noteworthy that a study demonstrated antiadipogenic effect of hexane, dichloromethane and methanol extracts of $A$. marmelos up to $100 \mu \mathrm{g} / \mathrm{mL}$, whereas the leaves extract had yielded 14 compounds from the dichloromethane as the extracting solvent and showed lipolytic activity up to $100 \mathrm{ug} / \mathrm{mL} .{ }^{[49]}$ Contrarily, this study exhibited the $\mathrm{EE}$ of $A$. marmelos indicating its cytotoxicity at a concentration of $25 \mu \mathrm{g} / \mathrm{mL}$ and reduced the cell viability to less than $50 \%$, possibly due to the discrepancy in the extraction solvent and method. Similarly, S. reticulata showed poor proliferation of cells that was less than $75 \%$ up to $100 \mu \mathrm{g} / \mathrm{mL}$ EE concentration, even though it has been earlier found that at $100 \mathrm{ug} / \mathrm{mL}$ of the WE, S. reticulata suppressed adipogenesis in 3T3-L1 adipocytes, ${ }^{[50]}$ confirming the importance of identifying the correct solvent to extract the targeted phytoconstituents responsible for a bioactivity. However, it was surprising that the relative lipid content of $A$. marmelos and $S$. reticulata significantly increased $(p<0.05)$ at $50 \mu \mathrm{g} / \mathrm{mL}$ EE level, while they were found to be toxic (Figure 2). As an explanation to this observation, we detected a significant differentiation of preadipocytes to adipocytes in the A. marmelos and S. reticulata treated wells similar to the rest of the treatments, however, after the D3, a partial layer of cells was recognized as dead. The reason for this observation is not yet investigated, probably may be due to the longer exposure time of the treatment to cells. A time-dependent treatment test would be ideal to unveil a clue in this regard. Further, the results of the present study demonstrated that the anti-obesity activity of screened plant parts does not show a relationship with the available quantity of phenolic and flavonoid contents.

The amount, quality, and activity of bioactive compounds present in different plant species depend on the type of plant part, the age of plants, climate, and type of solvent for extracting them. An arena of phytochemicals available in these crude extracts is responsible for different bioactivities offering grand health benefits to the human body. In Ayurvedic medication, crude WE is commonly used as a therapeutic agent. According to our findings, DW was found to be a better solvent for extracting bioactive compounds for many tested plant species while maintaining cell proliferation. However, ethanol was also found to be a modest extracting solvent with anti-adipogenic properties as a valueaddition. Since ancient times, it is common in Sri Lanka, where people prefer drinking herbal porridge known as "kola kenda" that is made by mixing different plant leaves, adding rice, boiling with water, and blending to get the final porridge product indicating the diversified therapeutic properties rendered to the human body by nature. Nevertheless, the findings of this study can be used as an indicator to optimize extraction solvents, cytotoxicity assays, and screening therapeutic effects on adipogenesis in future studies using these plants. To the best of our knowledge, this is the first study to evaluate the efficacy of different solvents, their cytotoxicity, and anti-adipogenic properties using an assortment of Sri Lankan medicinal plants.

\section{CONCLUSION}

The therapeutic value of any drug depends not only on its clinical efficacy, yet on its lack of toxic side-effects. The present experimental evidence supports the time-tested traditional claim for the usefulness of the water-based herbal mixtures of these commonly used medicinal plants as rich sources of phytochemicals. All the tested plants showed less or no toxicity when water was used as the extracting solvent while ethanolic extracts performed well in the anti-adipogenic activity. Further, no possible correlation was found between the phenolic content and anti-adiposity. In this investigation, we demonstrated different toxicity levels for different plant extracts enabling this information to be used as a diagnostic tool for the correct identification of these aqueous or ethanolic extracts and the development of a standardized pharmaceutical product that may be used by healers in Ayurvedic medication system.

\section{ACKNOWLEDGEMENT}

All the authors express their gratitude to the University of Sri Jayewardenepura for the financial assistance provided to conduct the research and acknowledge the services rendered by Department of Biochemistry and Clinical Chemistry, Faculty of Medicine, University of Kelaniya, Sri Lanka, in carrying out the in vitro cell line work.

\section{Financial Support and Sponsorship}

This study was financially supported by the University of Sri Jayewardenepura (Grant No: ASP/01/RE/TEC/2017/73).

\section{CONFLICT OF INTEREST}

The authors declare that there is no conflict of interest.

\section{ABBREVIATIONS}

DMEM: Dulbecco's modified Eagle medium; DMSO: Dimethyl sulfoxide; DW: Distilled water; EE: Ethanol extract; FBS: Fetal bovine serum; HE: Hexane extract; MTS: 3-(4, 5-dimethylthiazol-2-yl)-5-(3carboxymethoxyphenyl)-2-(4-sulfophenyl)-2H-tetrazolium; ORO: Oil Red O; PBS: Phosphate-buffered saline; PES: Polyethersulfone; PTFE: Polytetrafluoroethylene; TFC: Total flavonoid content; TG: Triglyceride; TPC: Total phenolic content; QE: Quercetin equivalents; WE: Water extract.

\section{REFERENCES}

1. Srivastava JP, Lambert J, Vietmeyer N. Medicinal plants: an expanding role in development. The World Bank, Washington D.C., World Bank Publications. 1996:1-20

2. Cragg GM, Newman DJ. Natural product drug discovery in the next millennium. Pharm Biol. 2001;39;Suppl 1:8-17. doi: 10.1076/phbi.39.s1.8.0009, PMID 21554167.

3. Zhang Y, Wu L, Ma Z, Cheng J, Liu J. Anti-diabetic, anti-oxidant and anti-hyperlipidemic activities of flavonoids from corn silk on STZ-induced diabetic mice. Molecules. 2015;21(1):E7. doi: 10.3390/molecules21010007, PMID 26703560.

4. Ghafar F, Nazrin TT, Salleh MM, Hadi NN, Ahmad N, Hamzah AA, Hadi NN, Ahmad N, Hamzah AA, Yusof ZAM, Azman IN. Total phenolic content and total flavonoid content in Moringa oleifera seed. Sci Herit J. 2017;1:23-5.

5. Zhu X, Ouyang W, Lan Y, Xiao H, Tang L, Liu G, Feng K, Zhang L, Song M, Cao Y. Anti-hyperglycemic and liver protective effects of flavonoids from Psidium 
guajava L.(guava) leaf in diabetic mice. Food Biosci. 2020;35. doi: 10.1016/j. fbio.2020.100574, PMID 100574

6. Kankanamalage TN, Dharmadasa RM, Abeysinghe DC, Wijesekara RG. A survey on medicinal materials used in traditional systems of medicine in Sri Lanka. J Ethnopharmacol. 2014;155(1):679-91. doi: 10.1016/j.jep.2014.06.016, PMID 24933220

7. Singh R, Verma PK, Singh G. Total phenolic, flavonoids and tannin contents in different extracts of Artemisia absinthium. J Intercult Ethnopharmacol. 2012;1(2):101-4. doi: 10.5455/jice.20120525014326.

8. Dhawan D, Gupta J. Research article comparison of different solvents for phytochemical extraction potential from Datura metel plant leaves. Int J Biol Chem. 2017;11:17-22.

9. Harborne JB. Phytochemicals methods. London: Hapman and Hall Ltd; 1973 p. 49-188.

10. Savithramma N, Rao ML, Suhrulatha D. Screening of medicinal plants for secondary metabolites. Middle East J Sci Res. 2011;8:579-84.

11. Yadav M, Chatterji S, Gupta SK, Watal G. Preliminary phytochemical screening of six medicinal plants used in traditional medicine. Int J Pharm Pharm Sci. 2012;6:539-42.

12. Lansakara K. Nutraceutical properties of Garcinia zeylanica fruit rinds and leaves [B.Sc. thesis]. Kelaniya, Sri Lanka: Faculty of Science, University of Kelaniya; 2017.

13. Kamtekar S, Keer V Patil V. Estimation of phenolic content, flavonoid content, antioxidant and alpha amylase inhibitory activity of marketed polyherbal formulation. J Appl Pharm Sci. 2014;4:61.

14. Vishwanath D, Srinivasan H, Patil MS, Seetarama S, Agrawal SK, Dixit MN, Dhar K Novel method to differentiate 3T3 L1 cells in vitro to produce highly sensitive adipocytes for a GLUT4 mediated glucose uptake using fluorescent glucose analog. J Cell Commun Signal. 2013;7(2):129-40. doi: 10.1007/s12079-012-0188-9, PMID 23292944.

15. Mohammedi Z, Atik F. Impact of solvent extraction type on total polyphenols content and biological activity from Tamarix aphylla (L.) Karst. Int J Pharm Biol Sci. 2011;2:609-15.

16. Oh TS, Choi DK, Yun JW. Morus alba L. root bark stimulates adipocyte differentiation in 3T3-L1 cells. Biotechnology Bioprocess Engineering 2011 Oct;16(5):978-86. doi: 10.1007/s12257-011-0174-8.

17. Nakamura S, Nakashima S, Oda Y, Yokota N, Fujimoto K, Matsumoto T, Ohta T, Ogawa K, Maeda S, Nishida S, Matsuda H, Yoshikawa M. Alkaloids from Sri Lankan curry-leaf (Murraya koenigii) display melanogenesis inhibitory activity: structures of karapinchamines A and B. Bioorg Med Chem. 2013;21(5):1043-9. doi: 10.1016/j.bmc.2013.01.012, PMID 23376010.

18. Nugara RN, Inafuku M, Iwasaki H, Oku H. Partially purified Peucedanum japonicum Thunb extracts exert anti-obesity effects in vitro. Nutrition. 2014;30(5):575-83. doi: 10.1016/j.nut.2013.09.017, PMID 24698349.

19. Akanji MA, Olukolu SO, Kazeem MI. Leaf extracts of Aerva lanata inhibit the activities of type 2 diabetes-related enzymes and possess antioxidant properties. Oxid Med Cell Longev. 2018;2018:3439048. doi: 10.1155/2018/3439048, PMID 30356437.

20. Hossin AY, Inafuku M, Takara K, Nugara RN, Oku H. Syringin: A phenylpropanoid glycoside compound in Cirsium brevicaule A. Gray Root modulates adipogenesis. Molecules. 2021;26(6):1531. doi: 10.3390/molecules26061531, PMID 33799634

21. Wei SD, Zhou HC, Lin YM. Antioxidant activities of extract and fractions from the hypocotyls of the mangrove plant Kandelia candel. Int J Mol Sci. 2010;11(10):4080-93. doi: 10.3390/ijms11104080, PMID 21152321.

22. Qian H, Nihorimbere V. Antioxidant power of phytochemicals from Psidium guajava leaf. J Zhejiang Univ Sci. 2004;5(6):676-83. doi: 10.1631/jzus.2004.0676.

23. Seo J, Lee S, Elam ML, Johnson SA, Kang J, Arjmandi BH. Study to find the best extraction solvent for use with guava leaves (Psidium guajava L.) for high antioxidant efficacy. Food Sci Nutr. 2014;2(2):174-80. doi: 10.1002/fsn3.91, PMID 24804076.

24. Dirar Al, Alsaadi DHM, Wada M, Mohamed MA, Watanabe T, Devkota HP Effects of extraction solvents on total phenolic and flavonoid contents and biological activities of extracts from Sudanese medicinal plants. S Afr J Bot. 2019;120:261-7. doi: 10.1016/j.sajb.2018.07.003.

25. Pushparaj P, Tan CH, Tan BK. Effects of Averrhoa bilimbi leaf extract on blood glucose and lipids in streptozotocin-diabetic rats. J Ethnopharmacol. 2000;72 (1-2):69-76. doi: 10.1016/s0378-8741(00)00200-2, PMID 10967456.

26. Kurup SB, Mini S. Attenuation of hyperglycemia and oxidative stress in streptozotocin-induced diabetic rats by aqueous extract of Averrhoa bilimbi LINN fruits. Int J Pharm Sci Res. 2014;5:4979.

27. Zakaria ZA, Zaiton $\mathrm{H}$, Henie EF, Jais AM, Zainuddin EN. In vitro antibacterial activity of Averrhoa bilimbi L. leaves and fruits extracts. Int J Trop Med. 2007;2:96-100.

28. Soumyanath A, Zhong YP, Gold SA, Yu X, Koop DR, Bourdette D, Gold BG. Centella asiatica accelerates nerve regeneration upon oral administration and contains multiple active fractions increasing neurite elongation in-vitro. J Pharm Pharmacol. 2005;57(9):1221-9. doi: 10.1211/jpp.57.9.0018, PMID 16105244.

29. Somboonwong J, Kankaisre M, Tantisira B, Tantisira MH. Wound healing activities of different extracts of Centella asiatica in incision and burn wound models: an experimental animal study. BMC Complement Altern Med. 2012;12:103. doi: 10.1186/1472-6882-12-103, PMID 22817824

30. Chauhan PK, Pandey IP, Dhatwalia VK, Singh V. Extract of Centella asiatica on alloxan induced diabetic rats. Int J Pharm Biol Sci. 2010;1:2.

31. Grotewold E, editor. The science of flavonoids. New York: Springer; 2006. p. 213-39.

32. Saha AK, Rahman MR, Shahriar M, Saha SK, Al Azad N, Das S. Screening of six ayurvedic medicinal plant extracts for antioxidant and cytotoxic activity. J Pharmacogn Phytochem. 2013;2:181-8.

33. Huang DJ, Hsien-Jung C, Chun-Der LI Y-HLI. Antioxidant and antiproliferative activities of water spinach (Ipomoea aquatica Forsk) constituents. Bot Bull Acad Sin. 2005;46:99-106.

34. Coqueiro A, Verpoorte R. Alkaloids, in reference module in chemistry, molecular sciences and Chemical Engineering. Elsevier Inc; 2015. p. 1-8.

35. Nugara RN, Inafuku M, Takara $\mathrm{K}$, Iwasaki H, Oku H. Pteryxin: a coumarin in Peucedanum japonicum Thunb leaves exerts antiobesity activity through modulation of adipogenic gene network. Nutrition. 2014;30(10):1177-84. doi: 10.1016/j.nut.2014.01.015, PMID 24993752.

36. Park E, Edirisinghe I, Choy YY, Waterhouse A, Burton-Freeman B. Effects of grape seed extract beverage on blood pressure and metabolic indices in individuals with pre-hypertension: a randomised, double-blinded, two-arm, parallel, placebo-controlled trial. Br J Nutr. 2016;115(2):226-38. doi: 10.1017/ S0007114515004328, PMID 26568249.

37. Valls RM, Llauradó E, Fernández-Castillejo S, Puiggrós F, Solà R, Arola L, Pedret A. Effects of low molecular weight procyanidin rich extract from french maritime pine bark on cardiovascular disease risk factors in stage-1 hypertensive subjects: randomized, double-blind, crossover, placebo-controlled intervention trial. Phytomedicine. 2016;23(12):1451-61. doi: 10.1016/j.phymed.2016.08.007, PMID 27765365.

38. Choi JS, Kim JH, Ali MY, Min BS, Kim GD, Jung HA. Coptis chinensis alkaloids exert anti-adipogenic activity on 3T3-L1 adipocytes by downregulating C/EBP- $\alpha$ and PPAR- $\gamma$. Fitoterapia. 2014;98:199-208. doi: 10.1016/j.fitote.2014.08.006, PMID 25128422.

39. Asano N, Yamashita T, Yasuda K, Ikeda K, Kizu H, Kameda Y, Kato A, Nash RJ, Lee HS, Ryu KS. Polyhydroxylated alkaloids isolated from mulberry trees (Morus alba L.) and silkworms (Bombyx mori L.). J Agric Food Chem. 2001;49(9):4208-13. doi: 10.1021/jf010567e, PMID 11559112.

40. Watson AA, Fleet GW, Asano N, Molyneux RJ, Nash RJ. Polyhydroxylated alkaloids-natural occurrence and therapeutic applications. Phytochemistry. 2001;56(3):265-95. doi: 10.1016/s0031-9422(00)00451-9, PMID 11243453.

41. Noble RL. The discovery of the vinca alkaloids-chemotherapeutic agents against cancer. Biochem Cell Biol. 1990;68(12):1344-51. doi: 10.1139/090-197, PMID 2085431.

42. Kim MY, Seguin P, Ahn JK, Kim JJ, Chun SC, Kim EH, Seo SH, Kang EY, Kim SL, Park YJ, Ro HM, Chung IM. Phenolic compound concentration and antioxidant activities of edible and medicinal mushrooms from Korea. J Agric Food Chem. 2008;56(16):7265-70. doi: 10.1021/jf8008553, PMID 18616260.

43. Kosinska A, Karamac M, Estrella I, Hernández T, Bartolomé B, Dykes GA Phenolic compound profiles and antioxidant capacity of Persea americana Mill. peels and seeds of two varieties. J Agric Food Chem. 2012;60(18):4613-9. doi: 10.1021/jf300090p, PMID 22494370.

44. Tayade AB, Dhar P, Sharma M, Chauhan RS, Chaurasia OP, Srivastava RB. Antioxidant capacities, phenolic contents, and GC/MS analysis of Rhodiola imbricata Edgew. Root extracts from Trans-Himalaya. J Food Sci. 2013;78(3):C402-10. doi: 10.1111/1750-3841.12054, PMID 23425091.

45. Li KK, Liu CL, Shiu HT, Wong HL, Siu WS, Zhang C, Han XQ, Ye CX, Leung PC, $\mathrm{Ko} \mathrm{CH}$ Cocoa tea (Camellia ptilophylla) water extract inhibits adipocyte differentiation in mouse 3T3-L1 preadipocytes. Sci Rep. 2016;6:20172. doi: 10.1038/ srep20172. PMID 26833256.

46. 46. El-Beshbishy HA, Singab AN, Sinkkonen J, Pihlaja K. Hypolipidemic and antioxidant effects of Morus alba L.(Egyptian mulberry) root bark fractions supplementation in cholesterol-fed rats. Life Sci. 2006;78(23):2724-33. doi: 10.1016/j. Ifs.2005.10.010, PMID 16313926.

47. Maneemegalai S, Naveen T. Evaluation of antibacterial activity of flower extracts of Cassia auriculata. Ethnobotanical Leaflets. 2010;2010:182-92.

48. Rajasekhar A, Peddanna K, Vedasree N, Munirajeswari P, Nagaraju N, Badri KR, Chippada AR. Antidiabetic activity of root tubers of Asparagus gonoclados Baker in streptozotocin induced diabetic rats. J Ethnopharmacol. 2019;242:112027. doi: 10.1016/j.jep.2019.112027.

49. Karmase A, Jagtap S, Bhutani KK. Anti adipogenic activity of Aegle marmelos Correa. Phytomedicine. 2013;20(14):1267-71. doi: 10.1016/j.phymed.2013.07.011, PMID 23972792.

50. Shimada T, Nagai E, Harasawa Y, Watanabe M, Negishi K, Akase T, Sai Y, Miyamoto K, Aburada M. Salacia reticulata inhibits differentiation of 3T3-L1 adipocytes. J Ethnopharmacol. 2011;136(1):67-74. doi: 10.1016/j.jep.2011.04.012 PMID 21511020. 
GRAPHICAL ABSTRACT

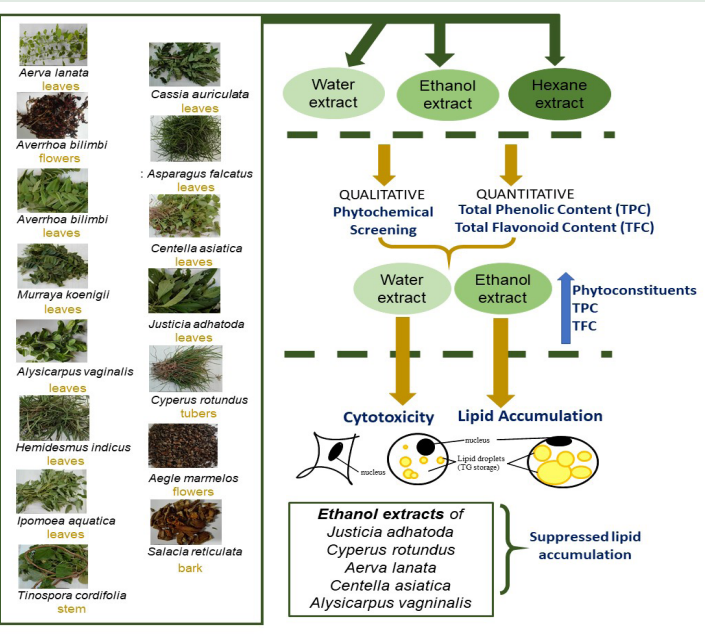

\section{SUMMARY}

The Ayurvedic medication play an important role in the traditional healing system in Sri Lanka. Fifteen commonly used medicinal plant parts were characterized in the present study using distilled water, ethanol and $n$-hexane as solvents. The presence of flavonoids, tannins, terpenoids, alkaloids, steroids, anthocyanins and coumarins were confirmed in both water and ethanol extracts. Hexane was the least phytoconstituents extractable solvent, while aqueous and ethanol extracts showed better phenolic and flavonoid contents. Many of the water extracts of plants showed no cytotoxicity even at $500 \mu \mathrm{g} / \mathrm{mL}$ in 3T3-L1 adipocytes, whereas the crude ethanol extracts showed a diversification in their concertation levels to maintain cell viability depending on the plant, however, was limited to levels below $100 \mu \mathrm{g} / \mathrm{mL}$. Interestingly, no possible correlation was found between the available phenolic content of extracts and anti-adipogenic activity. The findings of this study unveil avenues to the development of potential pharmaceutical products towards suppressing antiobesity.

\section{ABOUT AUTHORS}

Ms. Waruni Randika Silva, is a M.Phil student at the Faculty of Graduate Studies, University of Sri Jayewardenepura allied to Department of Biosystems Technology, Faculty of Technology, University of Sri Jayewardenepura. She is a passionate researcher on in vitro plant screening studies against obesity.

Dr. Ruwani Nilushi Nugara, is a Senior Lecturer, Department of Biosystems Technology, Faculty of Technology, University of Sri Jayewardenepura. Dr. Nugara's research interests are in vitro and in vivo plant screening studies against adiposity, puzzle solving of genetical modification patterns, and cellular metabolic pathway search due to phytoconstituents using next generation sequencing techniques. Her postgraduate studies were carried out at the Tropical Biosphere Research Center, University of the Ryukyus, Japan and Graduate School of Agriculture, Kagoshima University, Japan. She has served as a Research Fellow at the Center of Molecular Biosciences, Tropical Biosphere Research Center, University of the Ryukyus, Japan.

Snr. Prof. Pathmalal Manage, is a Professor of Zoology and Dean of the Faculty of Graduate Studies. He also acts as the Co-Chair, Research Council of University of Sri Jayewardenepura, and is the Director at Center for Water Quality and Algae Research, University of Sri Jayewardenepura. Prof. Manage's research interests are microbial ecology, bioremediation and ecotoxicology, biomonitoring, xenobiotics and natural toxins. His postgraduate studies were carried out at Faculty of Agriculture, Department of Life Environmental Conservation Science, Ehime University, Japan and Integrated College of Agriculture, Department of Life Environmental Conservation Science, Ehime University, Japan. He has also served as a Post-doc and Research Fellow since 2004 up to date in different Universities including Institute of Health and Safety Research (IHSR), Tsukuba, Japan and Robert Gordon University, UK.

Dr. Lanka Undugoda, is a Senior Lecturer, Department of Biosystems Technology, Faculty of Technology, University of Sri Jayewardenepura. Dr. Undugoda's research interests are food and nutrition, food microbiology, fermentation technology, bioremediation, biotechnology. Her postgraduate studies were carried out at Department of Plant Science and Molecular Biology, Faculty of Science, University of Kelaniya, Sri Lanka in the field of microbiology and biotechnology. She has been awarded with NRC SURED Award, National Research Council, Sri Lanka.

Dr. Dhanushka Udayanga, is a Senior Lecturer and Head, Department of Biosystems Technology, Faculty of Technology, University of Sri Jayewardenepura. Dr. Udayanga's research interests are plant and microbial biotechnology, plant diseases and fungal molecular systematics. His postgraduate studies were carried out at Mae Fah Luang University, Thailand affiliates to Centre of Excellence in Fungal Research. He has served as a Postdoctoral Visiting Scientist at Agricultural Research Services, United States Department of Agriculture, Beltsville, MD, USA.

Prof. Renuka Nilmini Liyanage, is the Dean, Faculty of Technology, University of Sri Jayewardenepura. Prof. Nilmini's research interests are development of enhanced performance of polymeric materials for various application platforms, rubber blends, natural fiber composites, polymer adhesion, rubber technology, NMR and biochemical structure identification. Her postgraduate studies were carried out at Cardiff University, UK. She also holds several national patents related to rubber and rubber processing technologies. 
Prof. Prasanna Galhena, is a Senior Lecturer, Department of Biochemical and Clinical Chemistry, Faculty of Medicine, University of Kelaniya. He also acts as the Coordinator, Centre for Natural Product Bioassay Screening, Faculty of Medicine, University of Kelaniya, Sri Lanka. His research interests are cancer genetics, herbal and complimentary medicine, proteomics in oral squamous cell carcinoma and clinical biochemistry. His postgraduate studies were carried out at University of Peradeniya, Sri Lanka, and University of Kelaniya, Sri Lanka. He has served as a Research Fellow at Indra Gandhi Centre for Atomic Research, India and Dept. of Human Genetics, Sri Ramachandra University, Chennai, India.

Cite this article: Silva WR, Nugara RN, Manage P, Undugoda L, Udayanga D, Liyanage RN, Galhena P. Effects of Extraction Solvents on Phytochemical Screening, Cytotoxicity and Anti-Obesity Activities of Selected Sri Lankan Medicinal Plants. Pharmacog Res. $2021 ; 13(5): 246-56$. 